\title{
The frequency and relationship of flowering plants on the distribution pattern of Ophiocordyceps sinensis (Yarchagunbu) in the highlands of Dolpa district, Nepal
}

\author{
S. Devkota ${ }^{1}$
}

\begin{abstract}
Ophiocordyceps sinensis (Berk.) G.H. Sung, J.M. Sung, Hywell-Jones \& Spatafora is a highly valuable medicinal fungus. Biologically it is an entomopathogenic, entomophagous or entomophilous fungus. In order to investigate different floral associations with $O$. sinensis, and to know different threats to pasture biodiversity, research was conducted in three pastures of Raha and Majphal Village Development Committees of Dolpa district. The study revealed that Juncus thomsonii and Bistorta macrophylla were the principal plant associates with $O$. sinensis as they dominated the alpine pasture vegetation. This research also highlighted the need for some proactive solutions along with conservation awareness program as important management initiatives to ensure ecological balance of O. sinensis.
\end{abstract}

Key words: Alpine zone, flora, Ophiocordyceps sinensis, pasture management, Yarsagumba

$\boldsymbol{O}$ phiocordyceps sinensis is a genus of entomophagous fungi (Pyrenomycetes, Ascomycotina) in the family Ophiocordycipitaceae. This parasitic fungus is variously known as Yarsagumba, Yarchagunbu, Kira, Jeevanbuti, Chyau, Chyau kira and Jara in Nepali, Yartsa gunbu in Tibetan, Dong chong xia cao in Chinese, Caterpillar fungus in English and Cordyceps in botanical term (Devkota, 2006, 2008a). Sherpas call them walking herb (Adhikari, 2000). There are about 300-400 species of Cordyceps distributed all over the world (Kobayasi, 1982; Sung, 1996). About 68 species have been reported from China and 33 species have been recognized in the Tibetan Plateau and Himalayan region (Zang \& Kinjo, 1998). Kobayasi \& Shimizu $(1960,1963)$ have worked on monographic study on Cordyceps and its allied species. From Nepal, 21 species of Cordycepioid fungi (Cordyceps and its allied species) have been reported (Adhikari, 2008b).

Zang \& Kinjo (1998) have described distinct, closely related species (Cordyceps gansuensis K. Zhang, C. Wang \& M. Yan, C. kangdingensis M. Zang \& Kinjo, and C. nepalensis M. Zang \& Kinjo) that in the past had been mistaken for C. sinensis. On the basis of molecular phylogenetic analysis Sung et al., (2007) made taxonomic revision of Clavicipataceous fungal group. According to them, the taxa fall in 3 monophyletic (clades) family. The family Clavicipataceae (Lindeu)
Earle ex Rogerson (Clade A) includes Metacordyceps Sung, Sung, Hywell-Jones \& Spatafora; Ophiocordycepitaceae Sung, Sung, Hywell-Jones \& Spatafora (Clade B) includes Elaphocordyceps Sung \& Spatafora and Ophiocordyceps Petch. and Cordycipitaceae Kreisel ex Sung, Sung, Hywell-Jones \& Spatafora (Clade C) includes Cordyceps Fr.

Ophiocordyceps sinensis fungus is endemic to the Tibetan Plateau including the adjoining high altitude areas of the Central and Eastern Himalayas (Nepal, Bhutan and the Indian states of Uttaranchal, Sikkim, Himanchal Pradesh and Arunachal Pradesh). The significance of the contribution of wild this edible fungus to rural livelihoods is acknowledged, but remains largely unexplored (Christensen et al., 2008). O. sinensis, famous as the gold rush of Nepal, has its niche in the alpine meadows/pastures between the altitudinal range of 3540 and $5050 \mathrm{~m}$ (Devkota, 2008a, 2008b). Its distribution is limited to areas where precipitation is below $300 \mathrm{~mm}$ per annum (Winkler, 2008).

Ophiocordyceps sinensis is found mostly in Dolpa, Darchula, Jumla, Bajura, Kalikot, Mugu, Humla, Rukum, Bajhang, Manang, Mustang, Gorkha, Lamjung, Dhading, Rasuwa, Dolakha, Sindhupalchowk, Solukhumbu, Sankhuwasabha, and Taplejung districts of Nepal (Adhikari, 2008a,

\footnotetext{
Asst. Lecturer, Central Department of Botany, Tribhuvan University, Kirtipur, Kathmandu, Nepal

E-mail:devkotashiva@yahoo.com
} 
Devkota, 2008a). Relative to Mustang district, Manang is far richer in the occurrence and distribution of $O$. sinensis within the Annapurna Conservation Area (Sherchan et al., 2005). Some of the other eastern Himalayan districts of Nepal stricken with acute poverty may also harbour the potential for commercial harvesting of $O$. sinensis; however, detailed exploration of the availability of this species is still warranted.

In the Tibetan plateau, the grasslands providing habitat for Hepialus moths and thus for Ophiocordyceps sinensis are associated with Kobresia sedges. The caterpillar of the moth lives in underground tunnels, emerging out at night to feed upon plant roots (Winkler, 2008). Among the sedges and grasses, Kobresia setchwanensis, Poa elanata, Festuca rubra are common. While among forbs, Potentilla anserina, Anemone rivularis, Primula sikkimensis, Aconitum rockii, Gentiana veitchiorum, Polygonum viviparum, Rheum alexandrae, Nardostachys chinensis, Pedicularis spp., Anaphalis flavescens, Meconopsis horridula are common (Wu, 1997; Zang \& Kinjo, 1998). Larvae of Hepialus also prefer to feed on young roots of plant species of the families of Polygonaceae, Fabaceae, Cyperaceae, and Poaceae (Chen et al., 2000).

Although few studies on the wild status of some medicinal plants have been carried out, several others, particularly at the high altitude species, are yet to be evaluated (Shrestha \& Joshi, 1996; IUCN, 2000; Lama et al., 2001). In this paper, floral associations of Ophiocordyceps sinensis, threats to $O$. sinensis in three different pastures and the impacts on the occurrence of this Himalayan treasure due to over grazing in Dolpa, Western Nepal have been analyzed. This
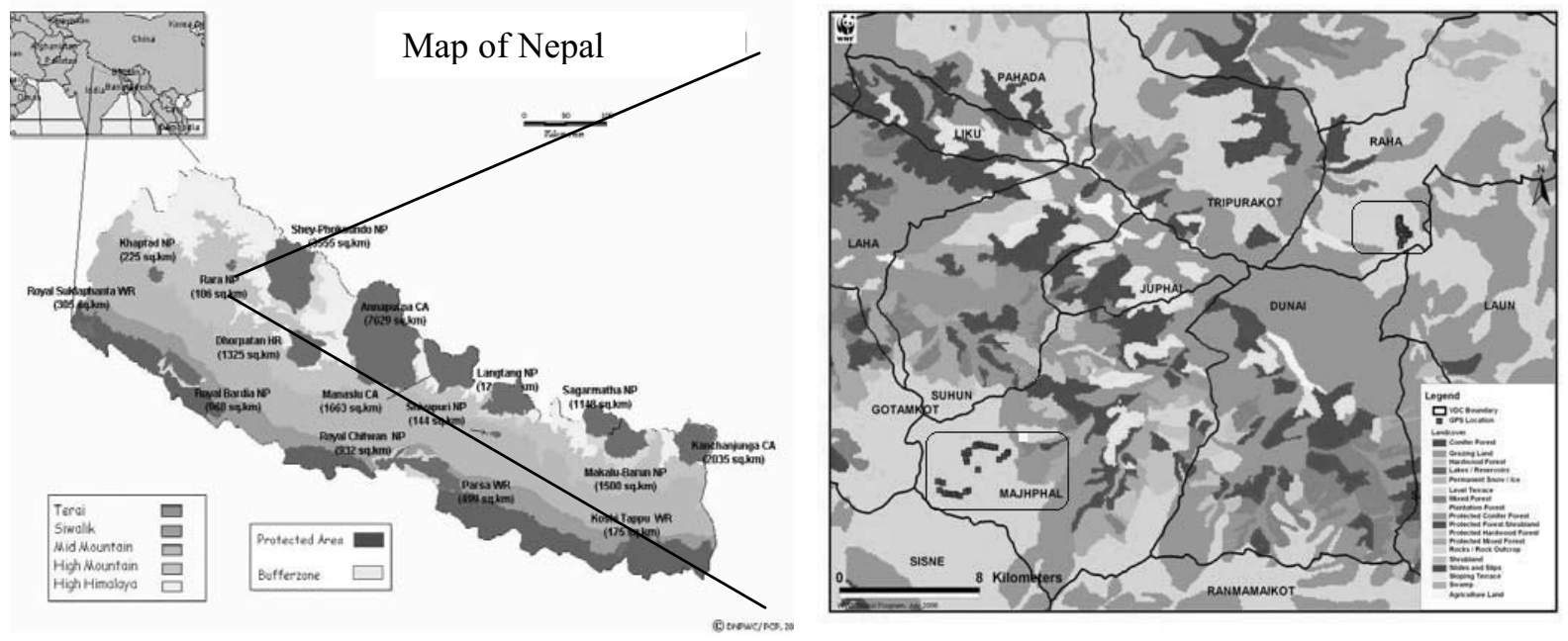

Figure 1: Showing study areas of Raha and Majphal VDCs of Dolpa district. 
plot was marked permanently with enamels and stones. Forty plots were established at Palma Ramana pasture of Raha VDC, 10 at Pokeypani and 30 at Saiquarry of Majphal VDCs were established. The plots were established between the altitudinal range of $3905 \mathrm{~m}$ to $4894 \mathrm{~m}$. The floral specimens collected from each permanent plot were recorded. Total numbers of Ophiocordyceps sinensis extracted by the collectors from the plots in the entire collection period were recorded.

Herbariums of collected plant specimens were prepared following the standard techniques (Martin, 1995; Lawrence, 1967). The collected plant specimens were identified with the help of standard literatures (Polunin \& Stainton, 1984; Stainton, 1972; Lama et al., 2001). All the herbariums were deposited in the Tribhuvan University Central Herbarium (TUCH).

\section{Results and Discussions}

The frequency and relationship of flowering plants on the distribution pattern of Ophiocordyceps sinensis during the collection period were recorded from the permanent plots of Raha and Majphal VDCs. The diverse groups of taxa are given in the Table 1. Altogether fifteen plant specimens belonging to ten families (Primulaceae, Ranunculaceae, Polygonaceae, Juncaceae, Compositae, Ericaceae, Euphorbiaceae, Rosaceae, Scrophulariaceae, Valerianaceae) were recorded from the study area.

The grasslands providing habitat for Ophiocordyceps sinensis were found to be predominantly of Juncus thomsonii and Bistorta macrophylla pastures. J. thomsonii covered most of the grasslands between the altitudinal range from $3000 \mathrm{~m}$ to nearly $5200 \mathrm{~m}$, gradually rising from the southeast to the northwest of the pastures. Chen et al., (2000) had also reported a similar distribution for Tibetan $O$. sinensis. Among the associated taxa, the top three plants with the highest frequencies were J. thomsonii, B. macrophylla and Rhododendron anthopogon. These were observed in 79, 68, and 40 plots, respectively. Within the 80 permanent plots, the least frequently associated plants were Androsace robusta, Primula macrophylla, Aconitum sp. and Rumex nepalensis, since they cropped up in only one, three, and four plots, respectively. The tender shoot of B. macrophylla resembled the fungal part of $O$. sinensis so the collectors were often confused.

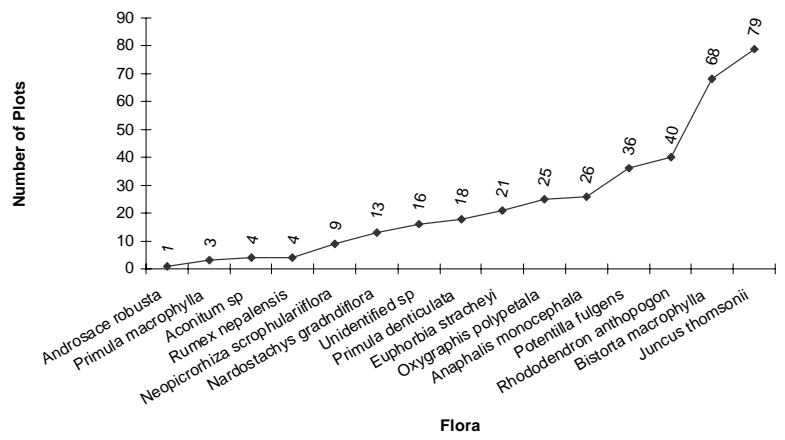

Figure 2: Number of sample plots and frequency of flowering plants.

Caterpillar fungus thrives in subalpine and alpine grasslands or meadows as well as open dwarf scrublands. In the study area, it was found naturally distributed from an altitudinal range of 3540 to $5050 \mathrm{~m}$ asl. Since the current actual tree line has been strongly influenced by human activities; wide swathes of forests in study areas have been replaced by pastures. Similar phenomenon was also reported from the Tibetan plateau (Winkler, 2000)

In the case of Dolpa, no clear difference was found in the distribution pattern of Opbiocordyceps sinensis on different aspects. Collectors extracted from all sunny aspects. According to Boesi (2003), in Lithang China, caterpillar fungus was mostly found on northfacing slopes. However Winkler (2008) reported its distribution in China on well-drained sunny slopes with lush grass vegetation. In Dolpa, O. sinensis was confined to rich pastures and sites which were too wet or waterlogged did not harbor populations of O. sinensis.

\section{Over grazing vs Distribution of Ophiocordyceps sinensis}

Animal husbandry is a vital part of the economy of the local peoples. Almost every household usually maintained a large herd of animals for manure, milk, meat and to plough their fields. These herds included mainly sheep, goats, horses, ponies, ass and zomo (hybrid of yak and cow) that foraged on pastures. People graze their livestock freely in the forest and on grasslands based on customary systems (Ghimire, 2005). Overgrazing leads to the loss of forest regeneration and the loss of grassland vegetation thereby inducing soil erosion (Singh, 2001; Jha, 2006). The animals destroy $O$. sinensis during grazing because they also feed on the host plants. The livestock annually brought onto the pastures by the local collectors destroy the ecological niche of $O$. sinensis. 
The collectors also reported that sites with less grazing effect had higher abundances of $O$. sinensis. Juncus thomsonii, Bistorta macrophylla, Anaphalis monocephala, Potentilla fulgens, were the plant species most affected by direct grazing and trampling effects. Similar views were also testified by collectors from Darchula district (Chettri \& Lodhiyal 2008). This study also confirmed that the permanent plots affected by grazing impact had poorer densities of $O$. sinensis than the plots far from grazing areas.

\section{Threats to the Ophiocordyceps sinensis in growing pastures in Dolpa}

A number of threats are annually posed to the habitat of Opbiocordyceps sinensis growing pastures in Dolpa and these threats are mainly of anthropogenic nature. It was found that more than 50,000 collectors romped around 25 or more pastures of Dolpa during 2006. The major threats were haphazard and unscientific collection of $O$. sinensis; soil and water pollution, excessive use of fuel wood, hunting of wildlife, and intentional fires burns to procure fuelwood and better grass production for cattle.

The collectors burn intentional fires for clearing the sites to facilitate the collection of $O$. sinensis and also to extract fuelwood for the next season. They have figured out that burned areas harbored more $O$. sinensis in the following year. The accidental and intentional fires have, however, had adverse effects on the forest biodiversity in the past. The plant species mainly used for fuel wood by the collectors were Rhododendron lepidotum, R. anthopogon, Juniperus sp., Betula utilis, and Quercus sp. Almost $100 \%$ of their energy resources were met from the nearby forests.

The majority of respondents (collectors/users $=74$, traders $=25$ and local healers $=3$ ) surveyed in this study also complained that thousands of collectors posed negative impacts to the soil of pastures after leaving lots of non-degradable materials like plastics and batteries. Similarly, increasing numbers of foot trails in the pastures were perceived to be deteriorating the virginity of the green pastures.

Illegal hunting of local fauna was also a common practice throughout the collection areas and had become one of the major threats for faunal biodiversity conservation. According to the respondents in 2005, some of the professional hunters hunted the wild animals to exchange the flesh or trophy for Ophiocordyceps sinensis. Pseudois nayaur (Naur) was the species most targeted for hunting.

\section{Maoists and Pastures Management}

The collection and trade of Opbiocordyceps sinensis in Dolpa was totally controlled by the Maoist in the study year. Realizing the potential destruction of $O$. sinensis, the local Maoists had drawn up 17 points "Code of Conduct" regarding different aspects, including pasture management. Some of the major codes related to pasture management were a) not to cut green trees for fuel; b) not to make a big hole in the pastures during collection c) not to release cattle in the pastures before collection (there was provision to allow cattle a week after the collection starts); d) not to discard plastics and batteries in the pastures; and e) not to hunt wild animals. Though they have attempted to implement these strict regulations, there was no alternative to fuel except to cut more trees.

\section{Conclusion}

From the study it can be concluded that Juncus thomsonii and Bistorta macrophylla exhibited a wide range of distribution in the pastures of Dolpa during the Ophiocordyceps sinensis collection period. It can be speculated that a healthy grassland environment is favorable for the caterpillar development as no informant reported abundant fruiting of the fungus in degraded areas. Plantations of Betula utilis, Rhododendron spp, and Juniperus spp. should be established at lower forests to supplement growing stock depleted by the extraction of fuelwood during collection seasons. To maintain a healthy pasture environment, over trampling effects and over grazing should be minimized and checked.

\section{Acknowledgements}

I am indebted to late Dr. D. P. Parajuli, Dr. K.C. Paudel, Dr. M. K. Adhikari and Dr. K. R. Bhattarai from the Ministry of Forests and Soil Conservation, Nepal for their ideas and suggestions prior to the field visits. Dr. Suresh K. Ghimire from Central Department of Botany, Tribhuvan University, is to be thanked for offering editorial comments to the early drafts of this manuscript. I am thankful to Mr. Maan B. Rokaya, Mr. Mani R. Shrestha and Mr. Ram K. Deo for their constructive assistance. WWF Nepal Program and SAFE Concern, Kathmandu provided financial and logistic supports for this study. 


\section{References}

Adhikari, M.K. 2000. Mushrooms of Nepal. P.U. Printers, Kathmandu, Nepal.

Adhikari, M.K. 2008a. Cordyceps in Nepal. In: Proceeding of Second National Seminar and Fair on Herbs. Organized by Herbs Products and Spices Trade Association, Nepalgunj. Pp.39-50

Adhikari, M.K. 2008b. The diversity of Cordycepioid fungi (Ascomycotina: Clavicipatales) reported from Nepal. Bulletin of Department of Plant Resources. 30: 1-7.

Boesi, A. 2003. The dbyar rtswa dgun bu (Cordyceps sinensis (Berk).Sacc): An important trade item for the Tibetan population of the Lithang Country, Sichuan Province, China. The Tibetan Journal 28.3:29-42.

Chen, S.J., Yin, D.H., Li, L., Zha, Xi., Shuen, J. H. and Zhama, C. 2000. Resources and distribution of Cordyceps sinensis in Naqu Tibet. Zhong Yao Cai 23.11:673-5.

Chhetri, R. and Lodhiyal, L.S. 2008. Collection of Cordyceps sinensis (Berk). Sacc. (yarsagomba) and its implications to rural livelihood and biodiversity conservation: A case of Darchula, Nepal. In: Medicinal Plants in Nepal: An Anthology of Contemporary Research. (eds. P.K Jha, S.B. Karmacharya, M.K. Chetri, C.B. Thapa and B.B. Shrestha). Ecological Society (ECOS), Kathmandu, Nepal. Pp. 214-223.

Christensen, M., Bhattarai, S., Devkota, S. and Larsen, H.O. 2008. Collection and use of wild edible Fungi in Nepal. Eco. Bot. 62(1) pp. 12-23.

Devkota, S. 2006. Yarsagumba [Cordyceps sinensis (Berk) Sacc.]: traditional utilization in Dolpa district, Western Nepal. Our Nature 4 (48-52).

Devkota, S. 2008a. Approach towards the Harvesting of Cordyceps sinensis (Berk.) Sacc. in Pastures of Dolpa, Nepal. In: Medicinal Plants in Nepal: An Anthology of Contemporary Research. (eds. P.K Jha, S.B. Karmacharya, M.K. Chetri, C.B. Thapa and B.B. Shrestha). Ecological Society (ECOS), Kathmandu, Nepal. Pp. 90-96.

Devkota, S. 2008b. Distribution and status of highland mushrooms: A study from Dolpa, Nepal. Jour. of Nat. Hist. Mus. 23 (51-59).

Ghimire, S.K. 2005. The endemic flora in Dolpa,
North-West Nepal: distribution patterns, Life forms, Habitat Specificity and Conservation Status. Botanica Orientalis 5. 35-39.

IUCN. 2000. National Register of Medicinal Plants. IUCN Nepal.

Jha, S. G. 2006. Linkages between biological and cultural diversity for participatory management: Nepal's experiences with Makalu-Barun National Park and its buffer zone. Banko Janakari. 16 (2): 37-44.

Kobayasi, Y. 1982. Keys to the taxa of the genera Cordyceps and Torrubiella. Trans Myco. Soc. Jap.. 23: 329-364.

Kobayasi, Y. and Shimizu, D. 1960. Monographic studies of Cordyceps. 1. group parasitic on Elaphomyces. Bull. of Nat. Scien. Mus., Tokyo. 5(2): 70-82.

Kobayasi, Y. and Shimizu, D. 1963. Monographic studies of Cordyceps. 2. group parasitic on Cicadidae. Bull. of Nat. Sci. Mus., Tokyo. 6 (3) 52: 286-314.

Lama Y. C., Ghimire, S.K. and Aumeeruddy Y. Thomas. 2001. Medicinal plants of Dolpo: Amchi's Knowledge and Conservation. WWF Nepal and People and Plants Initiative, Kathmandu, Nepal.

Lawrence, G. H. M. 1967. Taxonomy of Vascular Plants. Oxford \& IBH Publishing Co. Pvt. Ltd., New Delhi, India.

Martin, G. J. 1995. Ethnobotany: A People and Plants Conservation Manual. Chapman and Hall.

Polunin. O, and Stainton, J.D.A.1984. Flowers of the Himalaya. Oxford University Press. India.

Sherchan, R., Chapagain, N. R. and Chhetri, M. 2005. Distribution. Conservation practices and trade of Yarsagumba in Manang District of Annapurna Conservation Area, Nepal. Forestry (Jour. of Inst. of Fore., Nepal). 13. pp. 99-107.

Shrestha, T.B. and Joshi, R. M. 1996. Rare, Endemic and Endangered Plants of Nepal. WWF Nepal Program, Kathmandu, Nepal.

Singh, B. B. 2001. Socio-Economic Study of Makalu-Barun Landscape Complex. Final Report submitted to Nepal Biodiversity Landscape Project, Kathmandu, Nepal. 
Stainton, J. D. A.1972. Forests of Nepal. John Murray, London.

Sung, J. M. 1996. Cordyceps of Korea. Kyo-Hak. Publishing Co. Ltd., Seoul. 299 pp.

Sung, G. H., Hywell-Jones, N. L., Sung, J. M., Luangsa-ard, J. J., Shrestha, B. and Spatafora, J. W. 2007. Phylogenetic classification of Cordyceps and the clavicipitaceous Fungi. Stud. in Myco. 57:5-59.

Winkler, D. 2000. Patterns of forest distribution and the impact of fire and pastoralism in the forest region of the Tibetan Plateau. In: G. Miehe \& Zhang Yili (eds.): Environmental change in high Asia, Marburger Geographische Schriften 135: 201-227.
Winkler, D. 2008. Yartsa Gunbu (Cordyceps sinensis) and the fungal commodification of Tibet's rural economy. Eco. Bot., XX(X), 2008, pp. 1-15.

Wu, N. 1997. Ecological situation of high-frigid rangeland and its sustainability - A case study on the constraints and approaches in pastoral Western Sichuan/China. Abh. Anthropogeo. 55: 1-281.

Zang, M. and Kinjo, N.1998. Notes on the Alpine Cordyceps of China and nearby nations. Mycotaxon 66:215-229. 


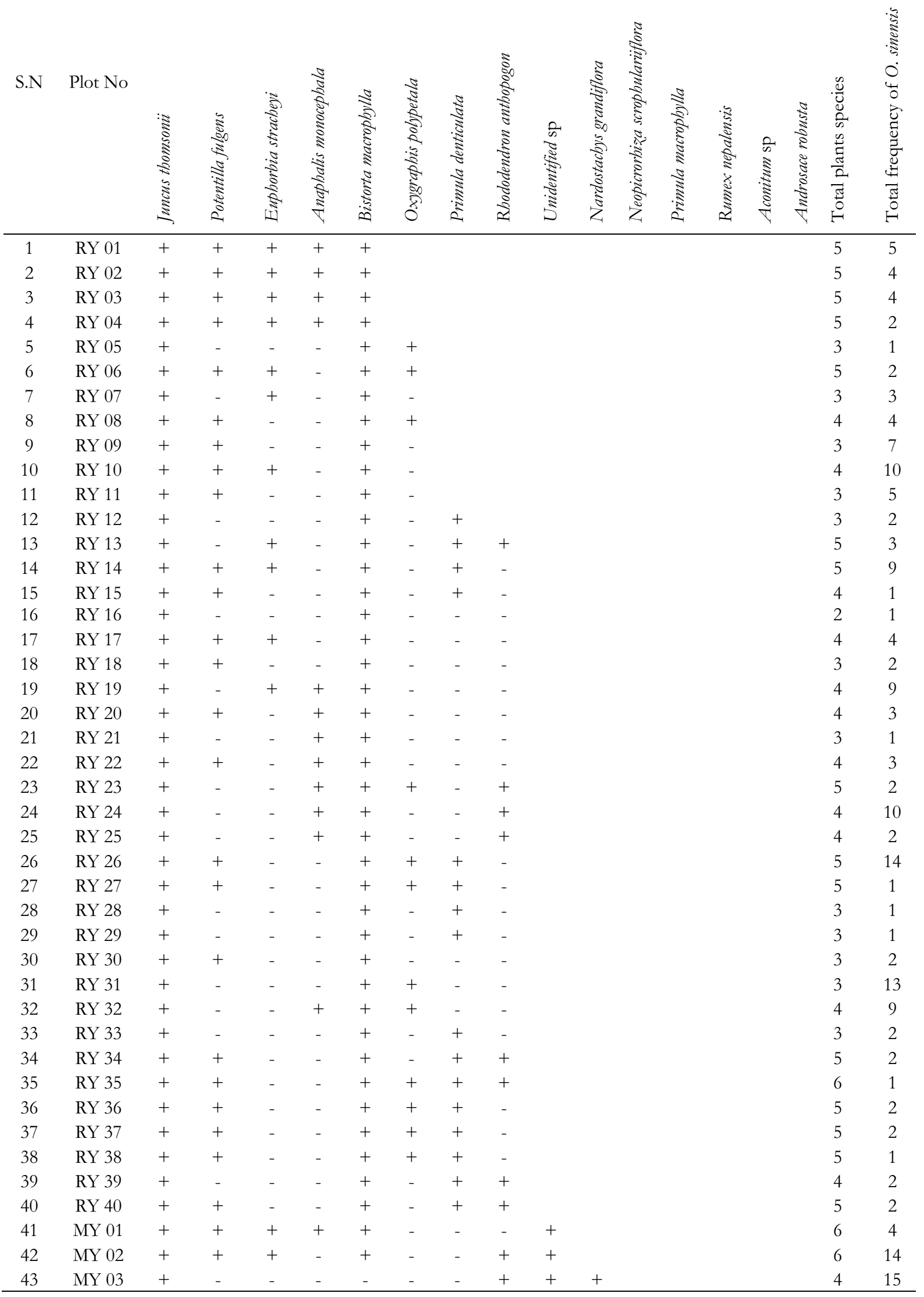




\begin{tabular}{|c|c|c|c|c|c|c|c|c|c|c|c|c|c|c|c|c|c|c|}
\hline 44 & MY 04 & + & - & + & + & - & + & - & + & + & - & & & & & & 6 & 19 \\
\hline 45 & MY 05 & + & + & - & - & - & + & + & + & - & + & + & & & & & 7 & 5 \\
\hline 46 & MY 06 & + & + & - & - & - & + & + & + & - & + & - & & & & & 6 & 19 \\
\hline 47 & MY 07 & - & - & - & - & - & + & - & + & + & + & - & & & & & 4 & 19 \\
\hline 48 & MY 08 & + & + & - & - & - & - & - & + & + & + & + & + & & & & 7 & 20 \\
\hline 49 & MY 09 & + & - & - & - & - & - & - & + & - & - & - & + & & & & 3 & 20 \\
\hline 50 & MY 10 & + & - & - & - & - & - & - & + & + & + & + & - & & & & 5 & 21 \\
\hline 51 & MY 11 & + & + & - & - & - & - & - & + & - & - & - & - & & & & 3 & 18 \\
\hline 52 & MY 12 & + & + & - & - & - & - & - & + & - & - & - & - & + & & & 4 & 24 \\
\hline 53 & MY 13 & + & + & - & - & - & - & - & - & + & - & - & - & + & & & 4 & 18 \\
\hline 54 & MY 14 & + & + & - & - & - & - & - & + & + & - & - & - & + & & & 5 & 11 \\
\hline 55 & MY 15 & + & - & + & + & + & - & - & + & + & - & - & - & - & & & 6 & 6 \\
\hline 56 & MY 16 & + & - & - & - & + & - & - & + & + & + & - & - & + & + & & 7 & 16 \\
\hline 57 & MY 17 & + & - & + & - & + & + & - & + & + & + & - & - & - & + & & 8 & 10 \\
\hline 58 & MY 18 & + & + & + & - & + & - & - & + & + & - & - & & - & - & & 6 & 18 \\
\hline 59 & MY 19 & + & - & - & + & + & - & - & + & + & - & - & - & - & - & & 5 & 21 \\
\hline 60 & MY 20 & + & - & - & + & + & - & - & + & - & - & - & - & - & - & & 4 & 10 \\
\hline 61 & MY 21 & + & - & - & + & + & - & - & + & + & - & - & - & - & - & & 5 & 11 \\
\hline 62 & MY 22 & + & - & - & - & + & - & - & + & - & - & - & - & - & - & & 3 & 11 \\
\hline 63 & MY 23 & + & - & - & + & + & - & - & + & - & - & - & - & - & - & & 4 & 21 \\
\hline 64 & MY 24 & + & - & - & + & + & + & - & + & - & - & - & - & - & - & & 5 & 11 \\
\hline 65 & MY 25 & + & - & - & + & + & + & - & + & - & - & - & - & - & - & & 5 & 13 \\
\hline 66 & MY 26 & + & - & - & - & + & - & - & + & - & - & - & - & - & - & & 3 & 25 \\
\hline 67 & MY 27 & + & - & - & - & + & - & - & - & - & - & - & - & - & - & + & 3 & 23 \\
\hline 68 & MY 28 & + & + & + & - & + & - & - & + & - & - & - & - & - & + & - & 6 & 11 \\
\hline 69 & MY 29 & + & - & + & + & + & + & - & + & - & - & - & - & - & - & - & 6 & 15 \\
\hline 70 & MY 30 & + & - & + & + & + & - & - & + & - & - & - & - & - & - & - & 5 & 14 \\
\hline 71 & MY 31 & + & - & - & - & + & - & - & - & - & - & - & - & - & - & - & 2 & 6 \\
\hline 72 & MY 32 & + & - & - & - & + & - & - & + & - & - & - & - & - & - & - & 3 & 5 \\
\hline 73 & MY 33 & + & - & - & + & + & + & - & + & - & - & - & - & - & - & - & 5 & 16 \\
\hline 74 & MY 34 & + & - & - & + & + & + & - & + & - & + & + & - & - & - & - & 7 & 15 \\
\hline 75 & MY 35 & + & - & - & + & + & + & - & - & - & + & + & - & - & - & - & 6 & 14 \\
\hline 76 & MY 36 & + & - & - & - & + & + & - & - & - & + & + & + & - & + & - & 7 & 3 \\
\hline 77 & MY 37 & + & - & - & - & + & + & - & + & - & + & + & - & - & - & - & 6 & 5 \\
\hline 78 & MY 38 & + & + & + & - & + & - & - & & & & & & & & & 4 & 22 \\
\hline 79 & MY 39 & + & - & - & - & + & - & - & + & - & - & + & - & - & - & - & 4 & 4 \\
\hline 80 & MY 40 & + & - & - & - & + & - & - & - & + & + & + & - & - & - & - & 5 & 12 \\
\hline \multicolumn{2}{|c|}{ Total } & 79 & 36 & 21 & 26 & 68 & 25 & 18 & 40 & 16 & 13 & 9 & 3 & 4 & 4 & 1 & & \\
\hline
\end{tabular}

\section{Note:}

RY = Raha Yarsagumba; MY = Majphal Yarsagumba; + = Present; - = Absent

Sunbuki, Dhochi $=$ Juncus thomsonii; Gorukajera $=$ Potentilla fulgens; Peitei Jasto $=$ Euphorbia stracheyi; Jhullya $=$ Anaphalis monocephala ; Nimbu, Nyakuri = Bistorta macrophylla; Pahelo tarey $=$ Oxygraphis polypetala ; Doeli phool $=$ Primula denticulata; Paluwa $=$ Rhododendron anthopogon; Narku $=$ Unidentified sp.; Bhutley $=$ Nardostachys grandiflora; Kutki $=$ Neopicrorbiza scrophulariflora; Katarey $=$ Primula macrophylla; Halhaley $=$ Rumex nepalensis.; Bikh $=$ Aconitum sp.; Begarey Jhar $=$ Androsace robusta. 